\title{
The B Subunit of the DNA Polymerase $\alpha$-Primase Complex in Saccharomyces cerevisiae Executes an Essential Function at the Initial Stage of DNA Replication

\author{
MARCO FOIANI, ${ }^{1 *}$ FEDERICA MARINI, ${ }^{1}$ DANIELA GAMBA, ${ }^{2}$ GIOVANNA LUCCHINI,, 3 \\ AND PAOLO PLEVANI ${ }^{1}$
} \\ Dipartimento di Genetica e di Biologia dei Microrganismi, 20133 Milan, ${ }^{1}$ Istituto Zooprofilattico Sperimentale, 25100 Brescia, ${ }^{2}$ and Istituto di Genetica, 07100 Sassari, ${ }^{3}$ Italy
}

Received 9 August 1993/Returned for modification 14 September 1993/Accepted 5 November 1993

\begin{abstract}
The four-subunit DNA polymerase $\alpha$-primase complex is unique in its ability to synthesize DNA chains de novo, and some in vitro data suggest its involvement in initiation and elongation of chromosomal DNA replication, although direct in vivo evidence for a role in the initiation reaction is still lacking. The function of the B subunit of the complex is unknown, but the Saccharomyces cerevisiae POL12 gene, which encodes this protein, is essential for cell viability. We have produced different pol12 alleles by in vitro mutagenesis of the cloned gene. The in vivo analysis of our 18 pol12 alleles indicates that the conserved carboxy-terminal two-thirds of the protein contains regions that are essential for cell viability, while the more divergent $\mathrm{NH}_{2}$-terminal portion is partially dispensable. The characterization of the temperature-sensitive pol12-T9 mutant allele demonstrates that the B subunit is required for in vivo DNA synthesis and correct progression through S phase. Moreover, reciprocal shift experiments indicate that the POL12 gene product plays an essential role at the early stage of chromosomal DNA replication, before the hydroxyurea-sensitive step. A model for the role of the B subunit in initiation of DNA replication at an origin is presented.
\end{abstract}

Biochemical and genetic evidence indicate that the DNA polymerase $\alpha$-DNA primase complex (Pol $\alpha$-primase) is involved in initiation of DNA replication at an origin and in the synthesis of Okazaki fragments on the lagging strand of the replication fork (reviewed in references 12, 37, and 67). Studies of simian virus 40 (SV40) DNA replication in vitro have demonstrated that Pol $\alpha$-primase, in conjunction with replication protein $A$ and $T$ antigen, is required for the initiation of DNA synthesis on duplex DNA molecules containing the SV40 origin of replication $(13,38,66)$. As the replication fork progresses, Pol $\alpha$-primase primes and extends new DNA chains on the lagging-strand template, as a result of its unique ability to start DNA synthesis de novo.

An in vitro yeast DNA replication system, capable of initiating DNA replication specifically and efficiently at yeast origin sequences (ARS), is still lacking. Therefore, the definition of the role of the yeast Pol $\alpha$-primase polypeptides depends on the analysis of their biochemical properties and on the production and characterization of mutations in the corresponding genes (for a review, see reference 12).

The structure and catalytic properties of the Pol $\alpha$-primase complex subunits are highly conserved in a wide range of eukaryotic organisms (67). The protein complex of the yeast Saccharomyces cerevisiae contains four polypeptides with apparent molecular masses of $180,86,58$, and $48 \mathrm{kDa}(7,53)$. The p180 polypeptide has been shown to be the catalytic Pol $\alpha$ subunit, while the DNA primase is a heterodimer of the 58 and $48 \mathrm{kDa}$ polypeptides $(6,7,52,53)$. We have shown that the p48 subunit is sufficient for RNA primer synthesis in vitro, although an auxiliary role for the $58-\mathrm{kDa}$ polypeptide in DNA primase activity in vivo cannot be excluded (62). In

* Corresponding author. Mailing address: Dipartimento di Genetica e di Biologia dei Microrganismi, Via Celoria 26, 20133 Milan, Italy. Phone: 39-2-26605222 or 39-2-26605219. Fax: 39-2-2664551. Electronic mail address: plevanip@imiucca.csi.unimi.it. fact, p58 mediates and/or stabilizes the binding of the catalytic p48 primase subunit to the p180 Pol $\alpha$ polypeptide (41).

Cloning of the $S$. cerevisiae POL1, PRI1, and PRI2 genes, which encode the p180, p48, and p58 subunits of the yeast complex, respectively, and the study of pol1, pri1, and pri2 lethal and conditional alleles have been essential in establishing the roles of the corresponding gene products in mitotic DNA replication and in identifying functional domains in the polymerase and primase polypeptides $(8,26,29$, $42,51,54)$. Moreover, pol1, pri1, and pri2 conditional mutants are defective in premeiotic DNA synthesis and show an enhanced rate of intrachromosomal recombination and spontaneous mutation, which is generally correlated with the severity of their defects in cell growth and DNA synthesis $(9,41,42)$. Since these mutant strains fail to accumulate high-molecular-weight DNA products $(9,29)$, the formation of nicked and gapped replicated DNA molecules might be responsible for the hyperrecombination phenotype usually found in yeast DNA synthesis mutants (33).

No enzymatic activity has been found to be associated with the $86-\mathrm{kDa}$ protein species (B subunit), which is tightly bound to the p180 polypeptide, and the physiological role of p86 is presently unknown (7). In vitro reconstitution studies with purified components indicate that $\mathrm{p} 86$ is not required for polymerase-primase interaction, and its presence does not change the catalytic properties of Pol $\alpha(6,7)$. Recently, it has been proposed that the human p86 homolog might serve as a molecular tether during DNA replication, because this subunit mediates the in vitro interaction between the human Pol $\alpha$-primase complex and T antigen bound to the SV40 origin of replication (14).

As a first step in identifying the physiological role of the B subunit of the yeast Pol $\alpha$-primase complex in vivo, we have mutagenized by the two-codon insertion mutagenesis method (3) the essential POL12 gene, which was recently found to encode the p86 polypeptide $(7,36 a)$. The analysis of 
the resulting mutations provides a map of essential domains of the B subunit. Furthermore, the characterization of a temperature-sensitive pol12 allele demonstrates that wildtype $\mathrm{p} 86$ is required for in vivo DNA synthesis and correct progression through $S$ phase. Finally, by mapping the POL12-dependent step with respect to the hydroxyurea (HU)-sensitive step, we found that the $86-\mathrm{kDa}$ B subunit plays an essential role at the early stage of chromosomal DNA replication.

\section{MATERIALS AND METHODS}

Plasmids. Plasmid pJN7 contains an 8.3-kb KpnI yeast genomic fragment carrying the POL12 gene in the pBluescript SK+ plasmid vector (Stratagene). Plasmid pAC27 was constructed as follows: the 3.1-kb LEU2 BglII fragment was used to replace the $1,458-b p B g l I I$ region internal to the $P O L 12$ open reading frame (ORF), and the generated $4.9-\mathrm{kb}$ SacI-KpnI fragment, with the disrupted POL12 gene, was then cloned in the pBluescript SK+ vector. Plasmids pJN7 and pAC27 were generous gifts from D. Hinkle (University of Rochester, Rochester, N.Y.). Plasmid pFE2 was produced by inserting the blunted 4.3-kb XbaI-NcoI fragment, containing the entire POL12 gene, into the NruI site of YCp50 (59). Plasmid pFE7 is a pFE2 derivative in which the genomic SacI site at position -143 from the first ATG of the POL12 ORF has been destroyed by T4 DNA polymerase treatment (61). This mutation does not cause any phenotypic change compared with pFE2. Plasmid pFE10 is a derivative of the ARS1 TRP1 CEN6 pLA411 plasmid (50) containing the blunted 4.3-kb XbaI-NcoI POL12 fragment inserted into the NruI site. Plasmid pFE3 contains the blunted 4.3-kb XbaI-NcoI POL12 fragment inserted into the blunted SalI site of YEp24 (59). Plasmid pFE118 is a pFE2 derivative containing a $S a c I$ site created in the $3^{\prime}$ noncoding region at position +2191 from the first POL12 ATG. Plasmid pFE132 contains the 2.8-kb EcoRI-SacI POL12 fragment from plasmid pFE118 inserted into plasmid pRS316 (64). Plasmid pFE135 is a pFE132 derivative in which the BamHI site at position +1946 from the first POL12 ATG has been filled in by Escherichia coli Klenow fragment treatment (61). Plasmid pFE130 carries the 2.9-kb SphI fragment from a pFE7 derivative plasmid, containing the pol12-T9 allele inserted between the EcoRI and NruI sites of YIp5, after filling in with Klenow fragment and exonucleolytic treatment with $\mathrm{T} 4$ DNA polymerase (61).

Yeast strains. Strain TD-28 (MATa ino1 ura3-52 can1) has been previously described (29). Strains H1514 (MAT $\alpha$ ura3-52 trp1-63 leu2-3,112) and H1515 (MATa ura3-52 trp1-63 leu23,112 ) were constructed by A. M. Cigan in A. G. Hinnebusch's laboratory (National Institutes of Health, Bethesda, Md.). CYd6 is a diploid strain obtained by crossing strains H1514 and H1515. One of the two copies of the POL12 gene in CYd6 has been disrupted by one-step gene replacement (59), by using the 4.1-kb SacI-KpnI fragment from plasmid pAC27, to generate strain CYd24. Strain CY46 (ura3-52 trp1-63 leu2-3,112 pol12::LEU2[pFE10 POL12 TRP1 CEN6]) is a meiotic segregant of a CYd24 transformant containing the pFE10 plasmid. Strain CY196 (MAT $\alpha$ ura3-52 trp1-63 leu2-3,112 pol12-T9) is isogenic to strain $\mathrm{H} 1514$ and was obtained by transformation of $\mathrm{H} 1514$ with plasmid pFE130 linearized with BamHI and subsequent 5-fluoroorotic acid treatment (59) of the obtained transformants; the replacement of the POL12 wild-type copy has been verified by Southern analysis. Strain CY211 was obtained by replacing the wild-type POL12 gene with the pol12-T9 allele in strain CG378 (MAT $\alpha$ ade5 can1 leu2-3 leu2-112 trp1-289 ura3-52) as described above for the construction of strain CY196.

Mutagenesis of the POL12 gene. To obtain two-codon insertions in the POL12 gene (3), plasmid pFE7 was linearized by partial digestion with TaqI or MaeII followed by ligation in the presence of the oligonucleotide $5^{\prime}$-CGAGCT$3^{\prime}$, which generates a single $S a c I$ site. The ligation mixture was cut with $S a c I$, and the 1.3-kb SacI fragment, containing the kanamycin resistance $\left(\operatorname{Kan}^{\mathrm{r}}\right)$ gene isolated from plasmid pUC4-KISS (Pharmacia), was added before ligation and transformation of the $E$. coli kanamycin-sensitive strain DH5 $\alpha$ (Bethesda Research Laboratories). To obtain twocodon insertions, $\mathrm{Kan}^{\mathrm{r}}$ insertion plasmids were digested with $S a c I$ and religated, leaving a SacI site between the cytosine and guanine nucleotides of each original TaqI and MaeII site. Plasmids were used to transform yeast strain CY46 either before or after excision of the $\operatorname{Kan}^{\mathrm{r}}$ cassette. Transformants were selected on SC plates without uracil and tryptophan (59) at $25^{\circ} \mathrm{C}$ and tested for their ability to grow on the same medium at different temperatures. No dominant phenotype was observed for any of the tested mutations. Transformants were then assayed for their ability to loose the TRP1 POL12 pFE10 centromeric plasmid after growth under nonselective conditions at $25^{\circ} \mathrm{C}$ by the plasmid-shuffling procedure (29). $\mathrm{Trp}^{-} \mathrm{Ura}^{+}$clones, containing the different pol12 alleles on the pFE7 derivative plasmids, were then assayed for their ability to grow when streaked on YPD or SC plates (59) incubated at different temperatures. Inframe deletions of the POL12 gene (see Fig. 4) were constructed by digestion with SacI of two plasmids containing different two-codon insertions followed by ligation on the same plasmid of the $\mathrm{NH}_{2}$ - and $\mathrm{COOH}$-terminal portions of POL12 derived from the two original mutant plasmids. The effect of the generated deletions was assayed in vivo as described above. The nature and extent of the insertion and deletion mutations were controlled by direct nucleotide sequencing.

Preparation of yeast extracts. Total protein extracts were prepared from $4 \times 10^{8}$ cells collected from logarithmically growing yeast cultures. Cells were washed with $20 \%$ trichloracetic acid in order to prevent proteolysis and were resuspended in $200 \mu \mathrm{l}$ of $20 \%$ trichloroacetic acid at room temperature. After addition of the same volume of glass beads, cells were disrupted by vortexing for $2 \mathrm{~min}$. Glass beads were washed twice with $200 \mu \mathrm{l}$ of $5 \%$ trichloroacetic acid, and the resulting extract was spun for $10 \mathrm{~min}$ at 3,000 $\mathrm{rpm}$ in an Eppendorf microcentrifuge at room temperature. The pellet was resuspended in $200 \mu$ l of Laemmli buffer (61), neutralized by adding $100 \mu \mathrm{l}$ of $1 \mathrm{M}$ Tris base, boiled for 3 min, and finally clarified by centrifugation as described above. Twenty-five-microgram aliquots of the extract, as determined by a Bio-Rad protein assay (61), were analyzed by polyacrylamide gel electrophoresis in the presence of sodium dodecyl sulfate (SDS-PAGE).

Production of monoclonal antibodies and Western blot (immunoblot) analysis. BALB/c mice were immunized subcutaneously with $30 \mu \mathrm{g}$ of Pol $\alpha$-primase complex immunopurified as previously described (53). The immunization protocol, fusion of spleen cells to NSO myeloma cells, and screening of hybridoma supernatants by enzyme-linked immunosorbent assay were performed according to published procedures (30). Positive hybridomas were tested for their ability to positively react with the $B$ subunit of the Pol $\alpha$-primase complex on Western blots of the purified complex, as previously described (25). Ascites fluids were pro- 
duced as previously described (62), and antibodies were isolated by protein A-Sepharose adsorption and elution.

Fluorescence-activated cell sorter (FACS) analysis. Cells were grown in YPD medium, sonicated for $15 \mathrm{~s}$, collected by centrifugation, and suspended in $70 \%$ ethanol for $16 \mathrm{~h}$. Cells were then washed in $0.25 \mathrm{M}$ Tris- $\mathrm{HCl}(\mathrm{pH} \mathrm{7.5)}$ and suspended in the same buffer containing $2 \mathrm{mg}$ of RNase A per $\mathrm{ml}$. Samples were incubated for $12 \mathrm{~h}$ at $37^{\circ} \mathrm{C}$ and collected by centrifugation, and the pellet was resuspended in $0.5 \mathrm{M}$ pepsin freshly dissolved in $55 \mathrm{mM} \mathrm{HCl}$. Cells were then washed in $180 \mathrm{mM}$ Tris- $\mathrm{HCl}$ (pH 7.5)-190 mM NaCl-70 mM $\mathrm{MgCl}_{2}$ and stained in the same buffer containing $50 \mu \mathrm{g}$ of propidium iodide per $\mathrm{ml}$. Samples were then diluted 10 -fold in $50 \mathrm{mM}$ Tris- $\mathrm{HCl}(\mathrm{pH} \mathrm{7.8)}$ and analyzed by using a Becton Dickinson FACScan.

Mapping the POL12-dependent step within the cell cycle by reciprocal shift experiments. The rationale of reciprocal shifts to map the order of events during the yeast cell cycle has been described previously $(32,55)$ and is discussed further in Results. Strain CY196 was used in experiments IA to IH of Table 2. In these experiments, the HU concentrations were 0.1 and $0.3 \mathrm{M}$, respectively, when used in the first and second incubations. In the first incubation it was necessary to keep the yeast cultures in the presence of $0.1 \mathrm{M} \mathrm{HU}$ for $3.5 \mathrm{~h}$ to obtain $>90 \%$ arrested cells. In the second incubation HU was used at $0.3 \mathrm{M}$ to prevent cells from bypassing the HU block. The shift to the restrictive temperature was performed for $4.5 \mathrm{~h}$ at $37^{\circ} \mathrm{C}$ to obtain $>90 \%$ arrested largebudded cells during the first incubation and to allow their efficient recovery. In the second incubation, the temperature was raised to $38^{\circ} \mathrm{C}$ to increase the tightness of the temperature-sensitive block. Exponentially growing CY196 cultures (about $90 \%$ budded cells) underwent the first incubation in YPD or YPD plus HU liquid medium, and, after mild sonication, cells were spotted on YPD or YPD plus HU agar plates for the second incubation. The percentage of budded cells present in the first incubation and producing adjacent pairs of large-budded cells in the second incubation was scored microscopically at different times. The values reported in Table 2 refer to the 6 -h time point, when $>90 \%$ of cells in the control experiments IC and IG gave raise to microcolonies in the second incubation. Strain CY211 was used in experiments IIA to IIE. In experiment IIA, an exponentially growing culture was shifted directly to $38^{\circ} \mathrm{C}$. In experiments IIB to IIE, cells were synchronized by addition of $2 \mu \mathrm{g}$ of $\alpha$-factor per ml (final concentration) and incubation at $25^{\circ} \mathrm{C}$ for $2.5 \mathrm{~h}$. Approximately 80 and $20 \%$ of the cells were, respectively, unbudded or large budded after this treatment. $\alpha$-factor was removed by filtration, and cells were either directly plated after sonication on YPD (experiments IIB and IIC) or resuspended in YPD liquid medium containing $0.1 \mathrm{M} \mathrm{HU}$ and incubated for an additional $2.5 \mathrm{~h}$ at $25^{\circ} \mathrm{C}$ before being plated on YPD (experiments IID and IIE). A 2.5-h incubation in the presence of HU was sufficient to obtain $>90 \%$ large-budded cells. The percentage of adjacent pairs of large-budded cells in the second incubation was scored as described above, and the values reported in Table 2 again refer to the 6-h time point.

\section{RESULTS}

Six independent mouse monoclonal antibodies recognize the 86-kDa polypeptide encoded by the POL12 gene. The secondlargest polypeptide (B subunit) of the yeast Pol $\alpha$-primase complex is encoded by the POL 12 gene $(7,36 a)$. This gene is essential for cell viability, since tetrads heterozygous for the
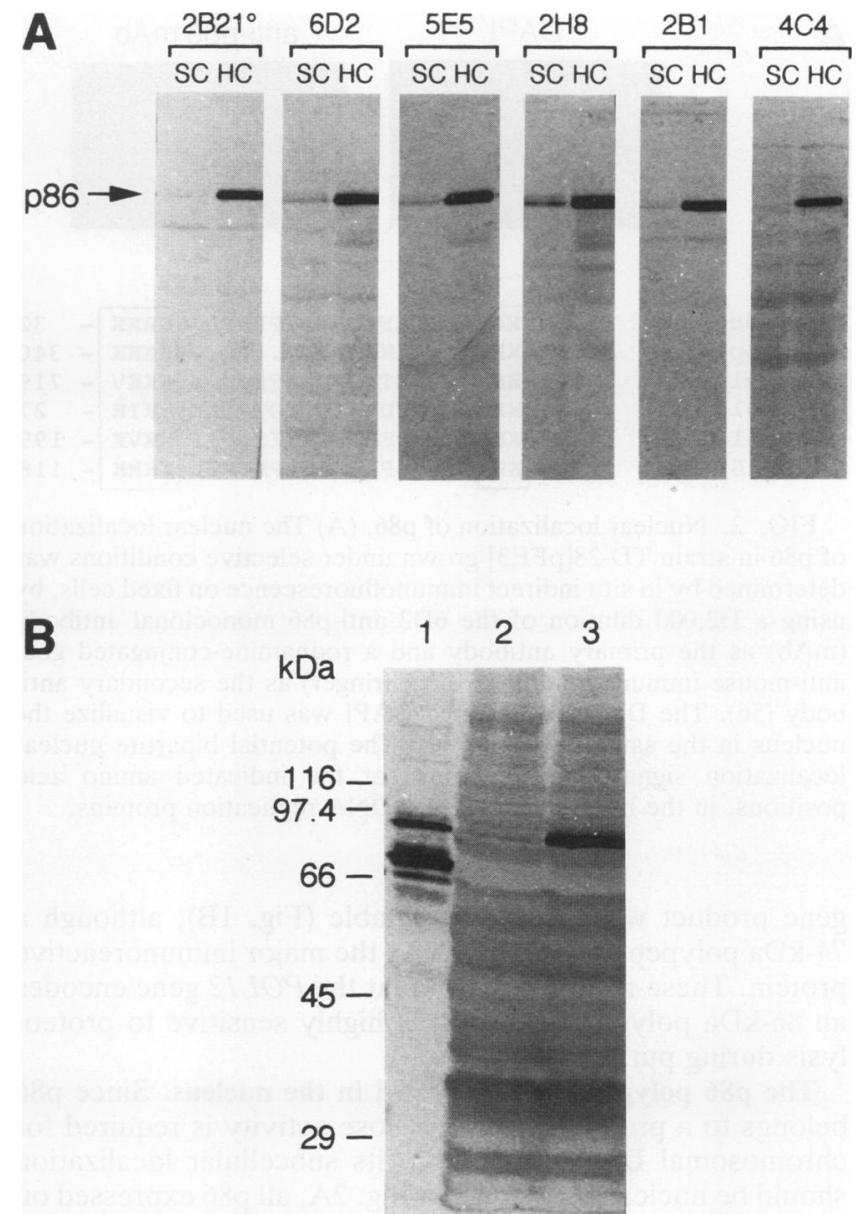

FIG. 1. Western blot analysis of crude extracts from yeast cells overexpressing the POL12 gene. (A) Hybridoma cell lines producing the 2B2, 6D2, 5E5, 2H8, 2B1, and 4C4 monoclonal antibodies were raised as described in Materials and Methods, and ascites fluids at a dilution of $1: 2,000$ were used to probe by immunoblotting $30 \mu \mathrm{g}$ of crude protein extract from strains TD-28[YEp24] (SC) and TD28 [pFE3] (HC). The position of the POL12 gene product $(86 \mathrm{kDa})$ is indicated by the arrow. (B) A mixture of the six monoclonal antibodies (1:2,000 dilution) was used to probe a Western blot containing an aliquot of immunopurified Pol $\alpha$-primase complex (lane 1) or $30 \mu \mathrm{g}$ of crude protein extract from strain TD-28[YEp24] (lane 2) or TD-28[pFE3] (lane 3).

POL12 disruption contain only two viable spores (data not shown). The predicted molecular mass of the POL12 gene product is $78.9 \mathrm{kDa}$, while the purified protein migrates as an 86-kDa polypeptide when analyzed by SDS-PAGE (7). Since most of our immunopurified Pol $\alpha$-primase complex preparations contain a major $74-\mathrm{kDa}$ protein band $(53,62)$ and a panel of monoclonal antibodies was produced against this complex, it was of interest to verify whether some of these antibodies recognized the $86-\mathrm{kDa}$ polypeptide in crude extracts when proteolysis was prevented.

As shown in Fig. 1A, six independent antibodies specifically identified an $86-\mathrm{kDa}$ protein species which is enriched in extracts from cells containing the POL12 gene on a high-copy-number plasmid. When an immunopurified Pol $\alpha$-primase complex was probed on a Western blot with a mixture of the six monoclonal antibodies, a band migrating with the same electrophoretic mobility as that of the POL12 
A
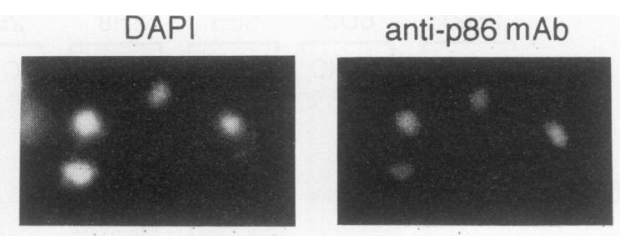

B

\begin{tabular}{|c|c|c|c|c|c|}
\hline$c d c$ & 10 & $\mathbf{K R}$ & IRRNLFDDAP & KRKK & \\
\hline Top2 & 327 & $\mathbf{K K}$ & ISEILKK. . . . . . . & KKKK & 340 \\
\hline $11 \varepsilon$ & 701 & - $\mathbf{K R}$ & ALQNETFPNKNKFS. . . . & KKKV & 719 \\
\hline & 4 & - $\mathbf{K R}$ & SLPMVDVKIDDEDTPQLE & KKIK & 27 \\
\hline 10 & 180 & $-\mathbf{K R}$ & VNGNDESSHDAGIS.... & KKVK & -199 \\
\hline & 95 & - $\mathbf{K K}$ & SLNSSPLFGLSIPKTPTL & KKRK & 118 \\
\hline
\end{tabular}

FIG. 2. Nuclear localization of $\mathrm{p} 86$. (A) The nuclear localization of p86 in strain TD-28[pFE3] grown under selective conditions was determined by in situ indirect immunofluorescence on fixed cells, by using a 1:2,000 dilution of the 6D2 anti-p86 monoclonal antibody $(\mathrm{mAb})$ as the primary antibody and a rodhamine-conjugated goat anti-mouse immunoglobulin $\mathrm{G}$ (Boehringer) as the secondary antibody (56). The DNA-binding dye DAPI was used to visualize the nucleus in the same cells (56). (B) The potential bipartite nuclear localization signal (boxed) found, at the indicated amino acid positions, in the listed $S$. cerevisiae DNA replication proteins.

gene product was clearly detectable (Fig. 1B), although a 74-kDa polypeptide was found as the major immunoreactive protein. These results confirm that the POL12 gene encodes an $86-\mathrm{kDa}$ polypeptide which is highly sensitive to proteolysis during purification.

The p86 polypeptide is localized in the nucleus. Since p86 belongs to a protein complex whose activity is required for chromosomal DNA replication, its subcellular localization should be nuclear. As shown in Fig. 2A, all p86 expressed on a high-copy-number plasmid under the control of its own promoter is detected in the nucleus by indirect immunofluorescence with monoclonal antibodies against the POL12 gene product. When the POL12 gene was present in single copy, no immunofluorescent cells were found under the same experimental conditions (data not shown). These data confirm the specificity of the immunological reagents used and suggest that $\mathrm{p} 86$ is present at a low level in a wild-type background.

Consistent with the finding that $\mathrm{p} 86$ is a nuclear protein, a survey of the primary amino acid sequence of the POL12 gene product identifies a region, spanning 23 residues from position 95 to position 118, containing two clusters of basic amino acids separated by an 18-amino-acid spacer (Fig. 2B). This bipartite motif functions as a nuclear localization signal (21) and is present in several yeast DNA replication proteins (Fig. 2B).

Two-codon insertion mutagenesis and deletion analysis of the POL12 gene. The amino acid sequence derived from the largest POL12 ORF shows significant homology with those of the corresponding subunits of the Pol $\alpha$-primase complex from human, mouse, and Drosophila melanogaster cells (14, 15, 43). Clusters of conserved amino acid residues are mostly confined within the $\mathrm{COOH}$-terminal two-thirds of these proteins (14). It is worth noting that the POL12 gene product exhibits weak homology (20\% identity and $41 \%$ similarity) also with the second-largest polypeptide (B subunit) of the yeast DNA Pol II $(\varepsilon)$ complex, encoded by the $D P B 2$ gene (1). The most conserved region among the p86 homologs is proximal to the carboxyl terminus and contains the VINPG motif, which is found also in the DPB2 gene product (Fig. 3). The $\mathrm{NH}_{2}$-terminal half of p86 is more divergent, although, as in the human homolog (14), several putative p34 Cdc28/cde2 phosphorylation sites can be found (data not shown).

In order to evaluate the physiological role of p86 and to define its putative functional domains, we mutagenized the POL12 gene on a centromeric plasmid by the two-codon insertion method (3). As described in more detail in Materials and Methods, an oligonucleotide that creates a new and unique $S a c I$ restriction site was inserted at random into various TaqI and MaeII sites in the POL12 gene (Fig. 4A), and linker insertions were selected by ligation of the bacterial $\mathrm{Kan}^{\mathrm{r}}$ gene in the $\mathrm{SacI}$ site. The mutated plasmids were tested for their abilities to complement the lethal effect of a chromosomal pol12::LEU2 disruption, either before or after the excision of the $\mathrm{Kan}^{\mathrm{r}}$ cassette, by assaying yeast cell viability and growth rates at $19,25,37$, and $39^{\circ} \mathrm{C}$ after plasmid shuffling. No complementation was found with plasmids carrying the $\mathrm{Kan}^{\mathrm{r}}$ cassette in the POL12 gene at all the positions indicated in Fig. 4B (data not shown). Therefore, the largest POL12 ORF is coextensive with the genetic complementation unit.

As summarized in Table 1, the two-amino-acid insertion Leu-261-Glu-Leu-Asp-262 (pol12-T7) resulted in cell lethality, while insertions Ile-417-Glu-Leu-Asp-418 (pol12-T9) and Asn-535-Glu-Leu-Val-536 (pol12-M2) caused temperature sensitivity for growth at $37^{\circ} \mathrm{C}$. All of the other twoamino-acid insertions (pol12-T2, pol12-T3, pol12-T5, pol12T6, and pol12-T8) had no effect. In-frame deletions (Fig. 4B) were also generated as described in Materials and Methods and tested as described above. From this analysis (Table 1) we found that neither the 30-amino-acid region spanning from Asp-6 to Val-35 (pol12- $\Delta T 2, T 3$ ) nor the 45-amino-acid region spanning from Ser-181 to Leu-224 (pol12- $\Delta T 4, T 6)$ was essential for $\mathrm{p} 86$ function. However, both a large in-frame deletion spanning from Glu-36 to Leu-261 (pol12- $\Delta T 3, T 7$ ) and a small deletion spanning from Glu-411 to Ile-417 (pol12$\Delta T 8, T 9)$ were lethal to the cell. Filling in of the BamHI site at position +1946 from the first ATG of the POL12 ORF generates a frameshift mutation leading to the synthesis of a protein lacking the last $\mathrm{COOH}$-terminal 41 amino acids of

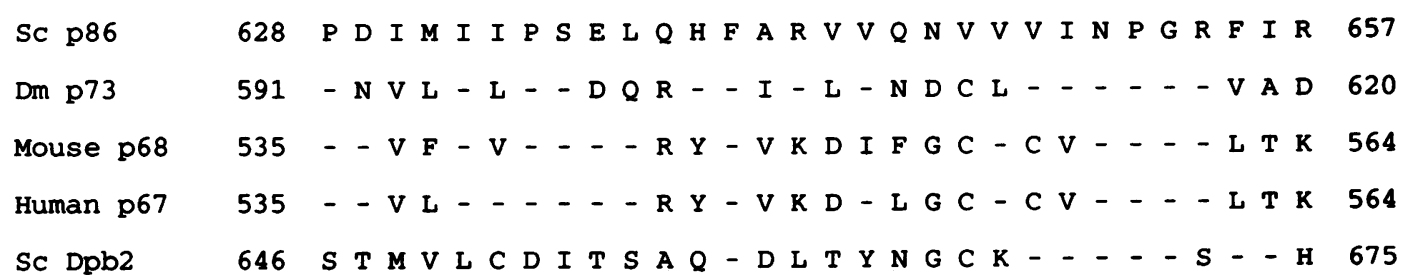

FIG. 3. A stretch of amino acids is conserved in the B subunits of DNA Pol $\alpha$ and Pol $\varepsilon$. Numbers indicate the borders of the compared regions. Only nonidentical amino acid residues are shown for polypeptides other than yeast p86. Sc, $S$. cerevisiae; Dm, D. melanogaster. 
A
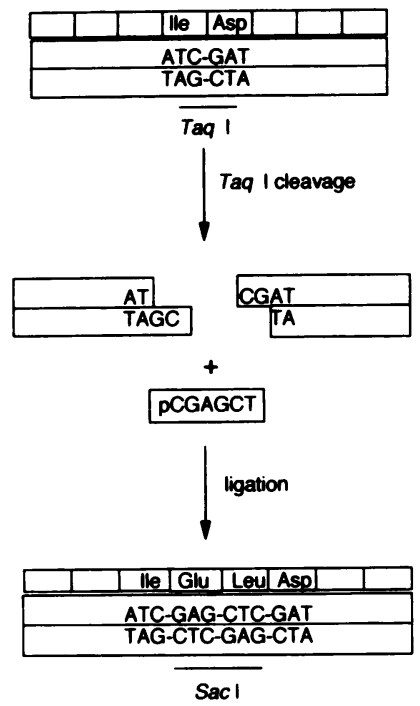

$\mathbf{B}$
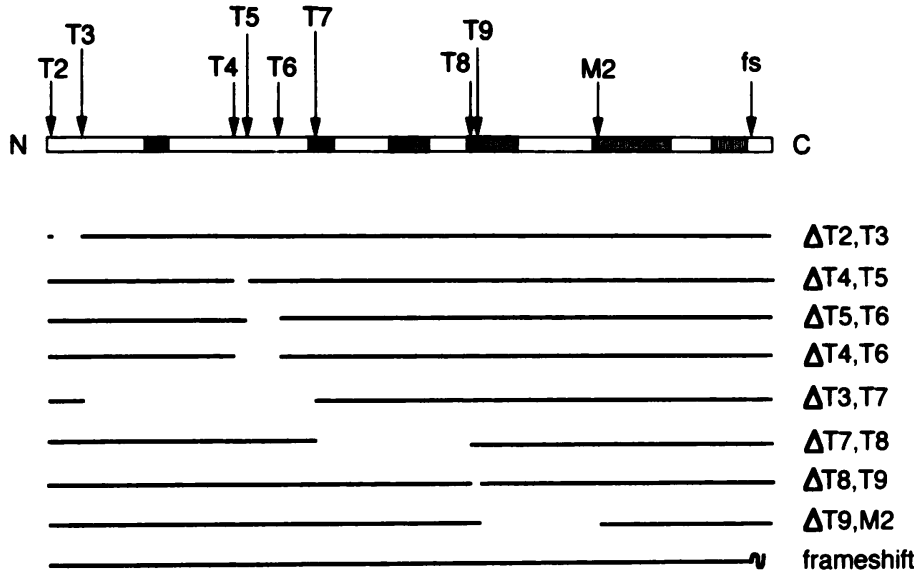

FIG. 4. Linker insertion mutagenesis of the POL12 gene. (A) Relevant steps of the two-amino-acid linker insertion mutagenesis method (see text for details). (B) The bar represents schematically the p86 protein, with arrows indicating the positions of the two-amino-acid insertions at TaqI (T2 to T9) and MaeII (M2) restriction sites, as well as the frameshift mutation at position +1946 (fs) of the POL12 ORF. The black box represents the putative nuclear localization signal, while the gray boxes indicate the amino acid regions conserved in the p86 homologs from other eukaryotes. In the bottom part of the figure, the in-frame deletions and the frameshift mutation described in the text are diagrammatically represented.

wild-type p86 and carrying an altered amino acid sequence from position 664 to 674 (Fig. 4B). This mutation is lethal, and therefore the p86 region from Ser-664 to Ser-705 is likely to be essential for p86 function.

TABLE 1. Growth phenotypes of the pol12 mutants $^{a}$

\begin{tabular}{llll}
\hline \multirow{2}{*}{ Allele } & \multicolumn{2}{c}{ Growth level $^{b}$ at: } & \multicolumn{1}{c}{ Insertion-deletion } \\
\cline { 2 - 3 } & \multicolumn{2}{c}{$25^{\circ} \mathrm{C}$} & \multicolumn{2}{c}{$37^{\circ} \mathrm{C}$} & \\
\hline Wild type & ++++++ & +++++++ & \\
T2 & ++++++ & +++++++ & I-5-EL-D-6 \\
T3 & +++++ & ++++++ & V-35-EL-E-36 \\
T5 & +++++ & ++++++ & T-193-SS-S-194 \\
T6 & ++++++ & +++++++ & L-224-SS-S-225 \\
T7 & - & - & L-261-EL-D-262 \\
T8 & ++++++ & +++++++ & L-410-EL-E-411 \\
T9 & +++ & $-1+$ & I-417-EL-D-418 \\
M2 & +++++ & + & N-535-EL-V-536 \\
$\Delta$ T2,T3 & ++++++ & +++++++ & E-6-L-36 \\
$\Delta$ T3,T7 & - & - & E-36-L-262 \\
$\Delta$ T4,T5 & ++++++ & +++++++ & S-181-S-194 \\
$\Delta$ T4,T6 & ++++++ & ++++++ & S-181-S-225 \\
$\Delta$ T5,T6 & ++++++ & +++++++ & S-194-S-225 \\
$\Delta$ T7,T8 & - & - & E-262-L-411 \\
$\Delta$ T8,T9 & - & - & E-411-L-418 \\
$\Delta$ T9,M2 & - & - & E-418-L-536 \\
Frameshift & - & - & S-664-ILCTNYCPMPZ
\end{tabular}

a Transformants of strain CY46 containing YCp50 derivatives carrying the indicated pol12 mutations and cured of the TRP1 plasmid carrying the POL12 wild-type gene were streaked on YPD plates, which were incubated at different temperatures.

${ }^{b}$ The level of growth was evaluated after 3 days. A minus indicates no growth, while the number of plus signs indicates the extent of growth compared with that of strains carrying the wild-type POL12 gene on plasmid pFE2, pFE7, or pFE132. No growth at both 25 and $37^{\circ} \mathrm{C}$ indicates the inability of the corresponding transformant to lose the POL12 copy on the TRP1 plasmid.

${ }^{c}$ The positions of the two-amino-acid insertions (boldface) and the boundaries of the in-frame deletions are indicated by numbers. The position of the frameshift mutation and the modified amino acid sequence (boldface) of the derived truncated protein are also shown. Amino acid residues are indicated in the one-letter code.
All of the two-amino-acid insertions causing either a lethal (pol12-T7) or a temperature-sensitive (pol12-T9 and pol12M2) phenotype are located within amino acid regions conserved in the p86 homologs from other species (Fig. 4B). All of the in-frame deletions without any detectable effect remove amino acid residues in nonconserved regions within the $\mathrm{NH}_{2}$-terminal third of the protein. Conversely, pol12$\Delta T 8, T 9$, which removes only seven amino acids in a conserved region, is lethal, as are larger deletions in both the $\mathrm{NH}_{2}$ - and $\mathrm{COOH}$-terminal halves of $\mathrm{p} 86$.

The POL12 gene product is required for in vivo DNA synthesis and for progression through $S$ phase. The production of a conditional mutation in the POL12 gene (pol12-T9) allowed us to investigate the physiological role of the corresponding gene product. Since the plasmid carrying the original pol12-T9 mutation was lost at high frequency, resulting in a slow-growth phenotype even at $25^{\circ} \mathrm{C}$ (Table 1), the wild-type chromosomal copy in strain H1514 was replaced with the pol12-T9 mutant allele (see Materials and Methods). The growth rates, cell morphologies, DNA contents, and kinetics of DNA synthesis of the wild-type and isogenic mutant strains were compared at the permissive and nonpermissive temperatures.

As shown in Fig. 5A, the growth rate of the pol12-T9 mutant strain at $25^{\circ} \mathrm{C}$ was only slightly different from that of the isogenic wild-type strain. Conversely, after the shift to the restrictive temperature $\left(37^{\circ} \mathrm{C}\right)$, the pol12-T9 strain exhibited a clear growth defect and mutant cells arrested as dumbbell-shaped cells with a single nucleus, as observed by 4',6-diamidino-2-phenylindole (DAPI) staining (data not shown).

Even at $25^{\circ} \mathrm{C}$, pol12-T9 cells were somewhat larger than normal and more likely than wild-type cells to be large budded, although the doubling times were similar in the two strains (110 and $100 \mathrm{~min}$, respectively). Furthermore, the percentage of unbudded $G_{1}$ cells at $25^{\circ} \mathrm{C}$ was significantly lower in the pol12-T9 strain than in the wild-type strain (Fig. $6 A)$. This reduced proportion of $G_{1}$ cells could result from a delay during progression through $\mathrm{S}$ phase. It has been shown 

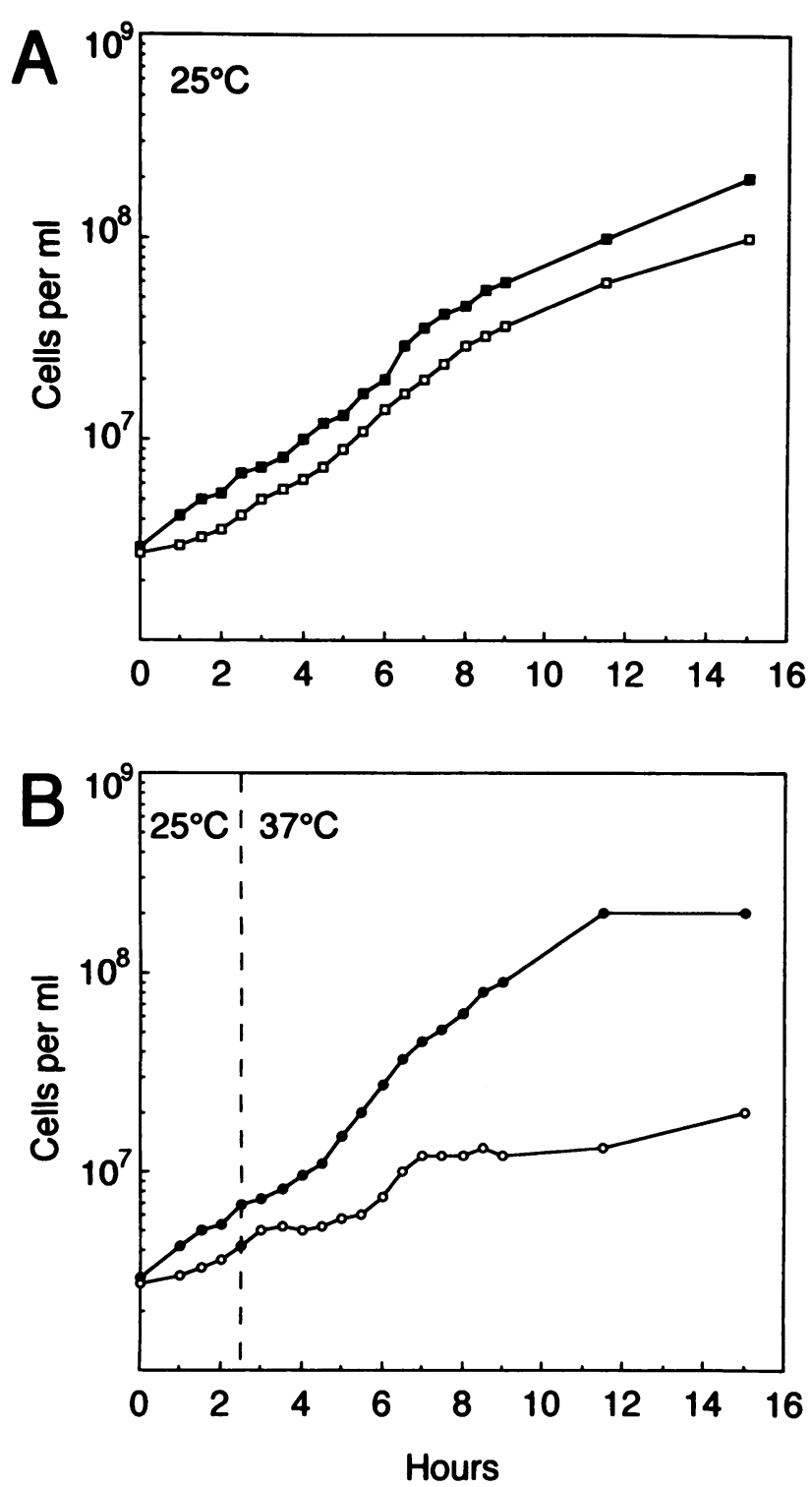

FIG. 5. Growth rate of the temperature-sensitive pol12-T9 mutant strain. Cultures of wild-type (closed symbols) and pol12-T9 (open symbols) cells, logarithmically growing at $25^{\circ} \mathrm{C}$, were divided into two aliquots, which were incubated at $25^{\circ} \mathrm{C}$ (A) or shifted to $37^{\circ} \mathrm{C}$ at the indicated time (B). Cell numbers were monitored by direct cell counting with a light microscope.

that a longer $\mathrm{S}$ phase leads to larger daughter cells at the time of cell separation, reducing the requirement for growth and time in $G_{1}$ in the subsequent cell cycle $(23,39)$. The decrease in the $\mathrm{G}_{1}$ population in the pol12-T9 strain is likely to be due to this indirect mechanism rather than to direct acceleration of the $\mathrm{G}_{1}-\mathrm{S}$ transition, because pol12-T9 cells are larger than wild-type cells. In fact, mutations that reduce the length of $G_{1}$ by accelerating the $G_{1}-S$ transition are usually associated with a smaller size (16). When the DNA contents of the mutant and wild-type cells were analyzed by FACS at both the permissive and nonpermissive temperatures, the pol12-T9 mutant strain was found to exhibit an abnormal DNA content even at $25^{\circ} \mathrm{C}$ (Fig. 6A). Consistent with the morphological observation, a very low proportion of mutant cells had a normal $G_{1} 1 C$ DNA content. Also, a higher
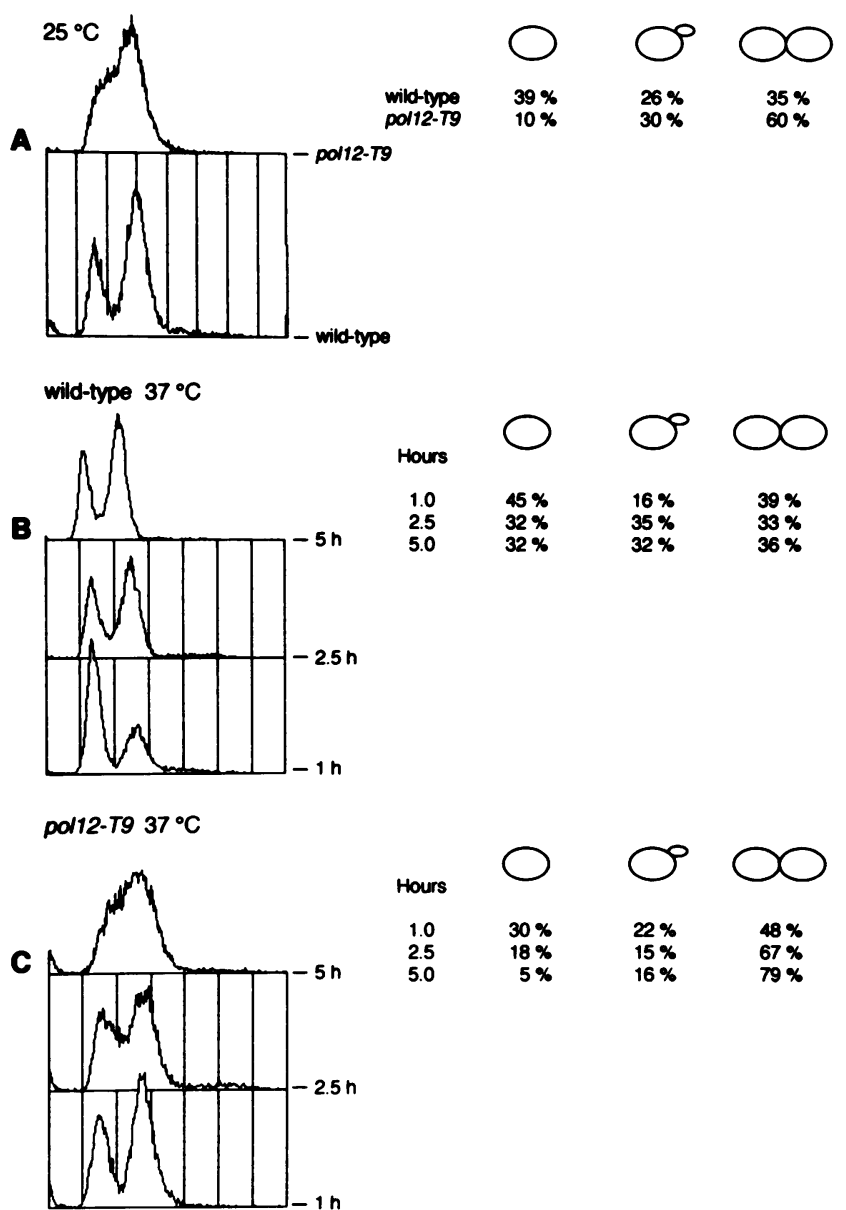

FIG. 6. Cell morphology and FACS analysis of wild-type and pol12-T9 cells. Samples from the cultures grown at 25 or $37^{\circ} \mathrm{C}$ shown in Fig. 5 were collected at the times indicated and analyzed morphologically and for DNA content by FACS. The percentages of unbudded, small-budded, and large-budded cells were determined after sonication for $15 \mathrm{~s}$ and fixation in an equal volume of $3.7 \%$ formaldehyde $-0.15 \mathrm{M} \mathrm{NaCl}$ followed by counting of 10 independent fields for a total of at least 200 cell units.

percentage of mutant cells than of wild-type cells were traversing $\mathrm{S}$ phase. After $1 \mathrm{~h}$ at $37^{\circ} \mathrm{C}$, the proportion of cells in $G_{1}$ increased in both the wild-type and mutant strains, as a result of the temperature shock (60) (Fig. 6B and C). However, the wild-type population exhibited a normal distribution of $G_{1}$ and $G_{2}$ cells after either 2.5 or $5 \mathrm{~h}$ at $37^{\circ} \mathrm{C}$, as determined by cell morphology and FACS analysis (Fig. $6 \mathrm{~B})$. Conversely, after $2.5 \mathrm{~h}$ at $37^{\circ} \mathrm{C}$ the pol12-T9 population accumulated an abnormal amount of S-phase cells, which were still present after $5 \mathrm{~h}$, at which time the majority had arrested as dumbbell-shaped cells with a nearly 2C DNA content (Fig. 6C). Therefore, the pol12-T9 mutation must affect cell cycle progression by increasing the length of $S$ phase. All of the defective phenotypes resulting from the pol12-T9 mutation, together with the biochemical evidence that p86 is tightly bound to the replicative DNA Pol $\alpha$, strongly suggest a direct role for the POL12 gene product in some aspects of chromosomal replication. To address this question more directly, we analyzed the kinetics of DNA synthesis in the wild-type and pol12-T9 strains at permissive and nonpermissive temperatures. As shown in Fig. 7A, no 

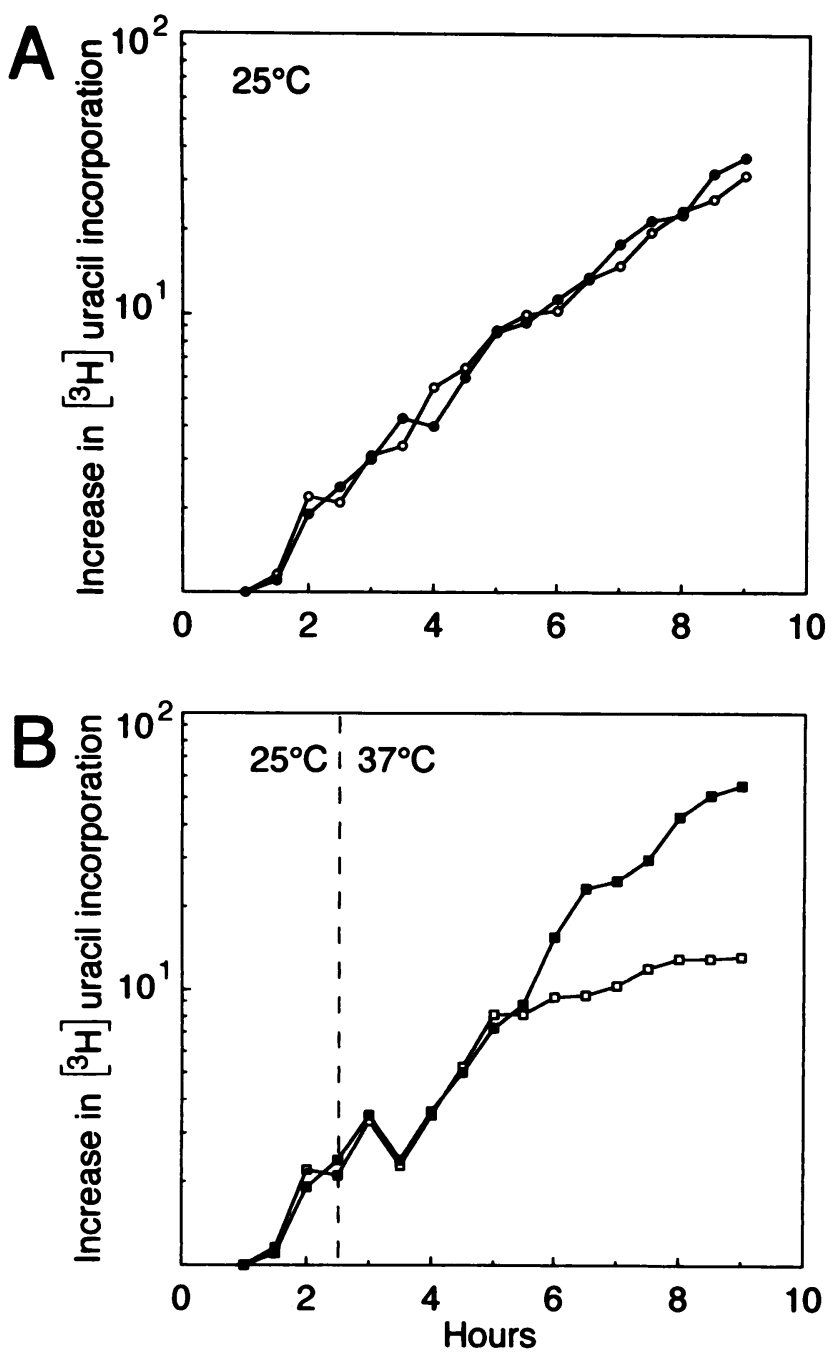

FIG. 7. Kinetics of DNA synthesis for wild-type and pol12-T9 mutant cells. Exponentially growing cultures at $25^{\circ} \mathrm{C}$ were supplemented with $\left[5,6-{ }^{3} \mathrm{H}\right]$ uracil at $7 \mu \mathrm{Ci} / \mathrm{ml}$ and were divided into two aliquots, which were incubated at $25^{\circ} \mathrm{C}(\mathrm{A})$ or shifted to $37^{\circ} \mathrm{C}$ at the indicated time (B). $\left[{ }^{3} \mathrm{H}\right]$ uracil incorporation into DNA or RNA was measured as previously described $(29)$. The increase in $\left[{ }^{3} \mathrm{H}\right]$ uracil incorporation is given as the ratio between the amount of radioactivity measured at the indicated times and that found after $1 \mathrm{~h}$ of incubation at the permissive temperature in the presence of the labeled precursor.

substantial difference in the incorporation of the labeled precursor into DNA was observed between the two strains at $25^{\circ} \mathrm{C}$. However, after the shift to the restrictive temperature, pol12-T9 cells exhibited a clear defect in DNA synthesis (Fig. 7B). A comparable defect in RNA synthesis was not observed (data not shown), indicating that the primary defect of this mutant is an impairment in DNA replication.

Mapping the POL12-dependent step within the yeast cell cycle by reciprocal shift experiments. The process of DNA replication can be divided into initiation, elongation, and termination events, which require different functions executed in a temporal order that can be established, in yeast cells, by using cell division cycle mutants ( $c d c$ mutants) and/or inhibitory drugs $(31,32,36,55)$. Among the different replication factors, the Pol $\alpha$-primase complex is peculiar, because it appears to play a bifunctional role during the initiation reaction, at an origin and in the elongation step (67, 68). However, it is unknown whether all components of the complex are involved in both reactions. Therefore, we decided to map the POL12-dependent step with respect to the HU-sensitive step, since it is known that HU inhibits the elongation reaction and causes cells to arrest as largebudded cells $(32,65)$. If the POL12 gene product was primarily involved in initiation of DNA replication, pol12 temperature-sensitive mutant cells would complete the cell cycle at the restrictive temperature after HU removal and arrest as adjacent pairs of large-budded cells (see Materials and Methods). Alternatively, if p86 played a role in DNA elongation and, therefore, the POL12-dependent step overlapped the HU-sensitive step, the shift from HU to the pol12 restrictive conditions would not allow the cells to proceed further in the cell cycle and they would arrest as single large-budded cells. Reciprocal shift experiments were carried out with pol12-T9 strains, and the results are summarized in Table 2 . When exponentially growing pol12-T9 cultures blocked with $\mathrm{HU}$ at the permissive temperature were shifted to $38^{\circ} \mathrm{C}$ (Table 2, experiment IA), over $80 \%$ of the cells could recover from the HU block, since they arrested as adjacent pairs of large-budded cells. A shift of exponentially growing pol12-T9 cultures (10\% unbudded and $90 \%$ budded cells) from 25 to $38^{\circ} \mathrm{C}$ (experiment IB) caused the cells to arrest either as single large-budded cells $(14 \%)$ or as pairs of adjacent large-budded cells $(86 \%)$, as expected for a tight mutation leading to arrest in the first cell cycle. The HU treatment was reversible and not lethal (experiment IC), since $89 \%$ of cells were able to form colonies after HU removal, although the HU block was complete throughout the experiment (experiment ID). These data suggest that the POL12 gene product is required before the HU-sensitive step. The results of experiments IE to IH in Table 2 are consistent with this interpretation. In fact, transfer of pol12-T9 cells from $37^{\circ} \mathrm{C}$ to $\mathrm{HU}$ at $25^{\circ} \mathrm{C}$ should cause growth arrest with cells as single large-budded cells if the HUsensitive step followed the step requiring the POL12 function. Indeed, the proportion of budded cells able to execute the HU-sensitive step (pairs of adjacent large-budded cells in HU) was markedly reduced when the first incubation was carried out at $37^{\circ} \mathrm{C}$ instead of $25^{\circ} \mathrm{C}$ (experiments IE and IF). The pol12-T9 arrest at $37^{\circ} \mathrm{C}$ was reversible (experiment IG), while the temperature-sensitive block was complete throughout the experiment (experiment IH).

To further confirm the ordering of the temperature-sensitive step with respect to the HU-sensitive step during the cell cycle, we performed the reciprocal shift experiment on $\alpha$-factor-synchronized pol12-T9 cultures (Table 2, experiments IIB to IIE). For this purpose we used strain CY211, which carries the pol12-T9 mutation in a genetic background different from that of strain CY196, which was used in the previous experiments. As shown by experiment IIA, strain CY211 behaves like strain CY196 when shifted from 25 to $38^{\circ} \mathrm{C}$. When cells were synchronized in $G_{1}$ with $\alpha$-factor and then released from the pheromone treatment at $38^{\circ} \mathrm{C}$ (experiment IIB), they arrested in the first cell cycle as single large-budded cells, as expected for a tight mutation affecting a function required after start. Conversely, cells completed the first cell cycle and arrested as pairs of adjacent largebudded cells when $\alpha$-factor-presynchronized cultures were incubated in the presence of $\mathrm{HU}$ and released from $\mathrm{HU}$ at $38^{\circ} \mathrm{C}$ (experiment IID). These data demonstrate that the POL12 gene product plays an essential role at the initial stage of the DNA replication, before the HU-sensitive step. 
TABLE 2. Mapping of the POL12-dependent step with respect to the HU-sensitive step

\begin{tabular}{|c|c|c|c|c|c|c|}
\hline \multirow{3}{*}{ Strain } & \multirow{3}{*}{ Expt } & \multirow{3}{*}{$\begin{array}{l}\text { Conditions }{ }^{a} \text { of } \\
\text { first incubation }\end{array}$} & \multicolumn{4}{|c|}{ Second incubation } \\
\hline & & & \multirow[b]{2}{*}{ Conditions $^{a}$} & \multirow{2}{*}{$\begin{array}{l}\text { Total no. of cells } \\
\text { examined }\end{array}$} & \multicolumn{2}{|c|}{$\%$ of budded cells that produce: } \\
\hline & & & & & $\begin{array}{l}\text { One large-budded } \\
\text { cell }\end{array}$ & $\begin{array}{l}\text { Two adjacent large- } \\
\text { budded cells }\end{array}$ \\
\hline \multirow{8}{*}{ CY196 } & IA & HU & $38^{\circ} \mathrm{C}$ & 115 & 16 & 84 \\
\hline & IB & $25^{\circ} \mathrm{C}$ & $38^{\circ} \mathrm{C}$ & 114 & 14 & 86 \\
\hline & IC & HU & $25^{\circ} \mathrm{C}$ & 120 & 11 & \\
\hline & ID & HU & HU & 100 & 91 & \\
\hline & IE & $37^{\circ} \mathrm{C}$ & HU & 104 & 81 & 19 \\
\hline & IF & $25^{\circ} \mathrm{C}$ & HU & 117 & 10 & 90 \\
\hline & IG & $37^{\circ} \mathrm{C}$ & $25^{\circ} \mathrm{C}$ & 107 & 15 & \\
\hline & IH & $37^{\circ} \mathrm{C}$ & $38^{\circ} \mathrm{C}$ & 103 & 97 & \\
\hline \multirow[t]{5}{*}{ CY211 } & IIA & $25^{\circ} \mathrm{C}$ & $38^{\circ} \mathrm{C}$ & 112 & 20 & 80 \\
\hline & IIB & $\alpha$-Factor & $38^{\circ} \mathrm{C}$ & 134 & 85 & 15 \\
\hline & IIC & $\alpha$-Factor & $25^{\circ} \mathrm{C}$ & 123 & 12 & \\
\hline & IID & $\alpha$-Factor $\rightarrow \mathrm{HU}$ & $38^{\circ} \mathrm{C}$ & 125 & 16 & 84 \\
\hline & IIE & $\alpha$-Factor $\rightarrow$ HU & $25^{\circ} \mathrm{C}$ & 142 & 10 & \\
\hline
\end{tabular}

\footnotetext{
a See Materials and Methods for details.
$b$ Cells gave rise to microcolonies in cases for which no number is given.
}

\section{DISCUSSION}

Chromosome replication in $\mathrm{S}$ phase is a central event in all eukaryotic cell cycles, and the timing of entry into $S$ phase is tightly regulated (reviewed in references $18,24,40$, and 57). Further, DNA replication is limited to once per cell cycle, and control mechanisms exist to prevent rereplication and entrance into mitosis when replication is not properly completed (reviewed in references 17, 22, 27, 33, 40, 46, and 49). However, the molecular details of turning replication on and off are still largely unknown (58). In fact, while a number of genes have been shown to be necessary for the linkage between the START commitment control and entry into S phase (reviewed in references 48 and 57), the molecular mechanisms which regulate the activity of the replication machinery are not yet understood. There is some evidence that essential replication proteins are modified in a cell cycle-dependent manner $(20,28,47)$, suggesting that entry and exit into $S$ phase might be modulated by posttranslational modifications that activate or repress the activity of replication factors.

Among the three DNA polymerases involved in chromosomal DNA replication (67), DNA Pol $\alpha$, with the tightly bound DNA primase, plays a peculiar function since it is involved both in initiation of DNA replication at an origin and in the elongation reaction. This dual role has been suggested by analysis of the biochemical and catalytic properties of the Pol $\alpha$-primase complex and by reconstitution studies with purified components, mostly performed with the SV40 in vitro DNA replication system (reviewed in references 37 and 67). However, direct in vivo evidence of the dual role of the Pol $\alpha$-primase complex is still lacking.

The four-subunit structure of the Pol $\alpha$-primase complex has been highly conserved in eukaryotic organisms as phylogenetically distant as yeasts and mammals (67). A protein, ranging in size from 67 to $86 \mathrm{kDa}$ (B subunit), has been found tightly associated with the $\mathrm{p} 180 \mathrm{Pol} \alpha$ polypeptide. In vitro reconstitution experiments indicate that yeast p86 is not required for the formation of a physical complex between Pol $\alpha$ and the primase polypeptides (6). Furthermore, p86 is not necessary for RNA primer formation and does not affect any of the parameters of Pol $\alpha$ catalysis, such as processivity or the $K_{m}$ for deoxynucleoside triphosphates or for the primer terminus (7). Nonetheless, a functional POL12 gene, encoding the $86-\mathrm{kDa} \mathrm{B}$ subunit, is required for cell viability, suggesting that this polypeptide performs an essential function. Recently, it has been shown that the human Pol $\alpha$-primase complex stimulates the ATP-dependent binding of SV40 T antigen to the viral origin of replication (44), and the $B$ subunit appears to play a crucial role in mediating the $T$ antigen-Pol $\alpha$-primase interaction (14).

The physiological characterization of the 18 different pol12 alleles described in this work, together with the finding that the B subunit of Pol $\alpha$-primase in all eukaryotic organisms analyzed so far shows conserved regions within the $\mathrm{COOH}$ terminal two-thirds of the proteins (14), suggests that this region might play an essential role for the interaction between $\mathrm{p} 86$ and the p180 Pol $\alpha$ polypeptide. In fact, all but one of the mutations in this region lead either to a temperaturesensitive phenotype or to cell lethality. Conversely, most of the two-amino-acid insertions in the more divergent $\mathbf{N H}_{2}$ terminal region, and even some significant amino acid deletions in this portion of the protein, do not cause any altered phenotype, although larger deletions in the same region, which include the nuclear localization signal, are lethal. Proteins likely to be involved in the initial stages of DNA replication, such as the Pol $\alpha$-primase complex and replication protein $A$, are involved in species-specific interactions $(5,45,63)$. The $\mathrm{NH}_{2}$-terminal 230 amino acids of the human Pol $\alpha$-primase B subunit are sufficient for in vitro interaction with $\mathrm{T}$ antigen (14), and it is known that this interaction is species specific (45). Therefore, the more divergent $\mathrm{NH}_{2}-$ terminal region of the Pol $\alpha$-primase $B$ subunit might have evolved to interact with species-specific key factors, such as origin recognition proteins, and therefore would lack the tight evolutionary constraints expected for protein domains involved in a catalytic function.

Among strains carrying the different mutations produced in the POL12 gene, the characterization of the pol12-T9 temperature-sensitive mutant strain allowed us to gain relevant information about the role of the Pol $\alpha$-primase B subunit in DNA replication in vivo. We have shown that the pol12-T9 mutant strain is impaired in DNA synthesis in vivo after shift to the nonpermissive temperature. Under restrictive conditions, cells arrest with a dumbbell shape, with an 
undivided nucleus at the neck between mother and daughter cells. This terminal phenotype is typical of budding-yeast DNA synthesis mutants (12).

When the cell morphology and DNA content of pol12-T9 cells were analyzed at the permissive and nonpermissive temperatures, cells showed a defect in cell cycle progression, probably because of an S-phase delay, and arrested with a nearly $2 \mathrm{C}$ DNA content. This finding is not surprising, because even cells with mutations in essential DNA polymerases often arrest with a greater-than-normal 1C DNA content $(2,10,68)$, and this behavior is interpreted to be a consequence of mutations which only partially affect the core replication machinery at the nonpermissive temperature. The observation that pol12-T9 cells can complete one round of cell division and DNA replication at the restrictive temperature before arresting with a nearly 2C DNA content could be the result of residual and abnormal DNA synthesis that may activate the $R A D 9$ checkpoint $(33,68)$. It will be of interest to verify the $R A D 9$ dependency of different pol12 alleles, since this dependency appears to be allele specific and is influenced by the experimental conditions (68).

Because eukaryotic DNA synthesis is initiated at multiple origins, it is impossible to distinguish, solely on the basis of DNA content, between a defect in initiation and one in elongation. For the same reason, a lag in $S$ phase does not distinguish incomplete initiation from an elongation defect. Because the Pol $\alpha$-primase complex appears to be involved in both the initiation and elongation steps of DNA replication, we used the pol12-T9 mutant to determine the time of action of the POL12 gene product with respect to the HU-sensitive step. We found that the B subunit of the Pol $\alpha$-primase complex is able to perform its function even when DNA elongation is inhibited by $\mathrm{HU}$, as has been observed for the $C D C 46$ (35) and $C D C 6(11)$ gene products, which also appear to have essential roles in initiation of DNA replication. The analysis of the pol12-T9 allele does not rule out the possibility that the $B$ subunit might also play a role in the elongation step of DNA replication, and more alleles will be produced and complementary approaches will be taken to clarify this point. Nonetheless, our results showing that p86 is required at a stage preceding the HU-sensitive step clearly imply that this protein is essential for initiation of DNA replication in vivo.

Defective interactions among proteins required for initiation of DNA replication would possibly result in a less efficient activation of replication origins, leading to an increase in the length of $S$ phase, as we detected in the pol12-T9 mutant. Since one of the initial stages of DNA replication requires the loading of the Pol $\alpha$-primase complex at an origin of replication, we suggest that the POL12 gene product mediates the interaction between the Pol $\alpha$-primase complex and proteins involved in modulating origin function (Fig. 8), such as the origin recognition complex (4), replication protein $\mathrm{A}(13)$, or the $C D C 6$ and $C D C 46$ gene products, whose biochemical functions are still unknown. The finding that the human B subunit mediates Pol $\alpha-T$ antigen interaction in vitro (14) is in agreement with this model. Since the origin recognition complex appears to be bound at yeast origins of replication during most or all of the cell cycle (19), it is reasonable to suggest that origin firing may be regulated by interactions with other critical protein factors (18). In this view, the p86 B subunit may have a regulatory function in activating DNA synthesis by loading the Pol $\alpha$-primase complex at the origin, either by direct interaction with the origin recognition complex or by mediating the assembly of the initiation complex through the interaction with replica-

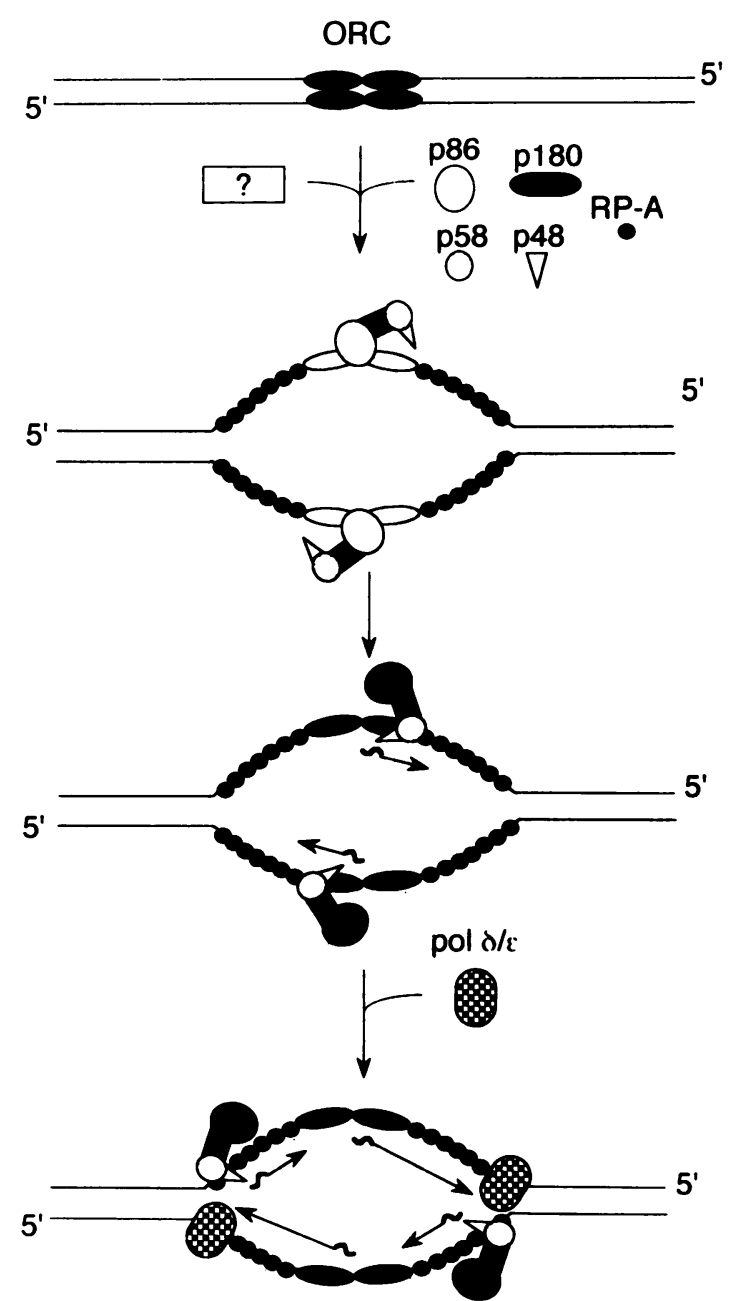

FIG. 8. Model for a regulatory role of the Pol $\alpha$-primase B subunit in initiation of DNA replication at an origin. Relevant proteins are indicated with different symbols. A change from black to white for the origin recognition complex (ORC) and p86 symbols indicates a change in the activity of these proteins (see text for details).

tion protein A or other, yet-unidentified key protein factors (indicated by the question mark in Fig. 8). We have recently found that the yeast Pol $\alpha$-primase B subunit is a stable protein which is posttranslationally modified in a cell cycledependent manner (unpublished data). Therefore, we propose that changes in the phosphorylation state of p86 might modulate the regulatory role of the $B$ subunit in origin firing.

\section{ACKNOWLEDGMENTS}

We are indebted to D. Hinkle (University of Rochester, Rochester, N.Y.), for communicating the nucleotide sequence of the POL12 gene and for the gift of plasmids pJN7 and pAC27, which were essential prerequisites for this work. We thank T. Kelly (Johns Hopkins University, Baltimore, Md.) for communicating results from his laboratory before publication. We are grateful to M. Baroni and D. Porro (University of Milan) for their help and assistance in FACS analysis. We thank Ricardo Capone for construction of some pol12 deletions, A. G. Hinnebusch (NICHHD, Bethesda, Md.) for yeast strains, and all the members of our laboratory for useful discussions and criticisms.

This work has been partially supported by grants from the Target Projects Biotechnology and Bioinstrumentation and Genetic Engi- 
neering, Centro Nazionale Ricerche of Italy, and by grant SC1-0479C(A) from the European Economic Community.

\section{REFERENCES}

1. Araki, H., R. K. Hamatake, L. H. Johnston, and A. Sugino. 1991. DPB2, the gene encoding DNA polymerase II subunit B, is required for chromosome replication in Saccharomyces cerevisiae. Proc. Natl. Acad. Sci. USA 88:4601-4605.

2. Araki, H., H. Hatake, A. Morrison, A. L. Johnson, L. H. Johnston, and A. Sugino. 1992. DNA polymerase II, the probable homolog of mammalian DNA polymerase $\varepsilon$, replicates chromosomal DNA in the yeast Saccharomyces cerevisiae. EMBO J. 11:733-740.

3. Barany, F. 1988. Procedures for linker insertion mutagenesis and use of new kanamycin resistance cassettes. DNA Protein Eng. Techniques 1:29-44.

4. Bell, S. P., and B. Stillman. 1992. ATP-dependent recognition of eukaryotic origins of DNA replication by a multiprotein complex. Nature (London) 357:128-134.

5. Brill, S. J., and B. Stillman. 1991. Replication factor-A from Saccharomyces cerevisiae is encoded by three essential genes coordinately expressed at $S$ phase. Genes Dev. 5:1589-1600.

6. Brooke, R. G., and L. B. Dumas. 1991. Reconstitution of the Saccharomyces cerevisiae DNA primase-DNA polymerase protein complex in vitro. J. Biol. Chem. 266:10093-10096.

7. Brooke, R. G., R. Singhal, D. C. Hinkle, and L. B. Dumas. 1991. Purification and characterization of the 180- and 86-kilodalton subunits of the Saccharomyces cerevisiae DNA primase-DNA polymerase protein complex. J. Biol. Chem. 266:3005-3015.

8. Budd, M., and J. L. Campbell. 1987. Temperature sensitive mutations in the yeast DNA polymerase I gene. Proc. Natl. Acad. Sci. USA 84:2838-2842.

9. Budd, M., K. D. Witrup, J. E. Balley, and J. L. Campbell. 1989. DNA polymerase $I$ is required for premeiotic DNA replication and sporulation but not X-ray repair in Saccharomyces cerevisiae. Mol. Cell. Biol. 9:365-376.

10. Budd, M. E., and J. L. Campbell. 1993. DNA polymerase $\delta$ and $\varepsilon$ are required for chromosomal replication in Saccharomyces cerevisiae. Mol. Cell. Biol. 13:496-505.

11. Bueno, A., and P. Russell. 1992. Dual functions of CDC6: a yeast protein required for DNA replication also inhibits nuclear division. EMBO J. 11:2167-2176.

12. Campbell, J. L., and C. S. Newlon. 1991. Chromosomal DNA replication, p. 41-146. In J. R. Broach, J. R. Pringle, and E. W. Jones (ed.), The molecular and cellular biology of the yeast Saccharomyces: genome dynamics, protein synthesis, and energetics. Cold Spring Harbor Laboratory Press, Cold Spring Harbor, N.Y.

13. Collins, K. L., and T. J. Kelly. 1991. Effects of T antigen and replication protein $A$ on the initiation of DNA synthesis by DNA polymerase $\alpha$-primase. Mol. Cell. Biol. 11:2108-2115.

14. Collins, K. L., A. A. R. Russo, B. Y. Tseng, and T. J. Kelly. 1993. The role of the $70 \mathrm{kDa}$ subunit of human DNA polymerase $\alpha$ in DNA replication. EMBO J. 12:4555-4566.

15. Cotterill, S., R. I. Lehman, and P. McLachlan. 1992. Cloning of the gene for the $73 \mathrm{kD}$ subunit of the DNA polymerase $\alpha$ primase of Drosophila melanogaster. Nucleic Acids Res. 20: 4325-4330.

16. Cross, F. R. 1988. $D A F 1$, a mutant gene affecting size control, pheromone arrest, and cell cycle kinetics of Saccharomyces cerevisiae. Mol. Cell. Biol. 8:4675-4684.

17. Dasso, M., and J. W. Newport. 1990. Completion of DNA replication is monitored by a feedback system that controls the initiation of mitosis in vitro: studies in Xenopous. Cell 61:811823.

18. Diffley, J. F. X. 1992. Early events in eukaryotic DNA replication. Trends Cell Biol. 2:298-303.

19. Diffiey, J. F. X., and J. H. Cocker. 1992. Protein-DNA interactions at a yeast replication origin. Nature (London) 357:169-172.

20. Din, S. U., S. J. Brill, M. P. Fairman, and B. Stillman. 1990. Cell cycle regulated phosphorylation of DNA replication factor A from human and yeast cells. Genes Dev. 4:968-977.

21. Dingwall, C., and R. A. Laskey. 1991. Nuclear targeting se- quences-a consensus? Trends Biochem. Sci. 16:478-481.

22. Enoch, T., and P. Nurse. 1991. Coupling M-phase and S-phase: controls maintaining the dependence of mitosis on chromosome replication. Cell 65:921-923.

23. Epstein, C. B., and F. R. Cross. 1992. CLB5: a novel B cyclin from budding yeast with a role in S-phase. Genes Dev. 6:16951706.

24. Fangman, W. L., and B. J. Brewer. 1992. A question of time: replication origins of eukaryotic chromosomes. Cell 71:363-366.

25. Foiani, M., A. M. Cigan, C. J. Paddon, S. Harashima, and A. G. Hinnebusch. 1991. GCD2, a translational repressor of the GCN4 gene, has a general function in the initiation of protein synthesis in Saccharomyces cerevisiae. Mol. Cell. Biol. 11:3203-3216.

26. Foiani, M., C. Santocanale, P. Plevani, and G. Lucchini. 1989. A single essential gene, $P R I 2$, encodes the large subunit of DNA primase in Saccharomyces cerevisiae. Mol. Cell. Biol. 9:30813087.

27. Forsburg, S. L., and P. Nurse. 1991. Cell cycle regulation in the yeasts Saccharomyces cerevisiae and Schizosaccharomyces pombe. Annu. Rev. Cell Biol. 7:227-256.

28. Fotedar, R., and J. M. Roberts. 1992. Cell cycle phosphorylation of RPA-32 occurs within the replication initiation complex. EMBO J. 11:2177-2187.

29. Francesconi, S., M. P. Longhese, A. Piseri, C. Santocanale, G. Lucchini, and P. Plevani. 1991. Mutations in conserved yeast DNA primase domains impair DNA replication in vivo. Proc. Natl. Acad. Sci. USA 88:3877-3881.

30. Galfré, G., and C. Milstein. 1981. Preparation of monoclonal antibodies: strategies and procedures. Methods Enzymol. 73:353.

31. Hartwell, L. H. 1971. Genetic control of cell division cycle in yeast. II. Genes controlling DNA replication and its initiation. J. Mol. Biol. 59:183-194.

32. Hartwell, L. H. 1976. Sequential function of gene products relative to DNA synthesis in the yeast cell cycle. J. Mol. Biol. 104:803-817.

33. Hartwell, L. H., and S. Smith. 1985. Altered fidelity of mitotic chromosome transmission in cell cycle mutants of $S$. cerevisiae. Genetics 110:381-395.

34. Hartwell, L. H., and T. A. Weinert. 1989. Checkpoints: controls that ensure the order of cell cycle events. Science 246:629-634.

35. Hennessy, K., C. D. Clarck, and D. Botstein. 1991. Subcellular localization of yeast $C D C 46$ varies with the cell cycle. Genes Dev. 4:2252-2263.

36. Hereford, L. M., and L. H. Hartwell. 1974. Sequential gene function in the initiation of Saccharomyces cerevisiae DNA synthesis. J. Mol. Biol. 84:445-461.

36a. Hinkle, D. Personal communication.

37. Hurwitz, J., F. B. Dean, A. D. Kwong, and S. H. Lee. 1990. The in vitro replication of DNA containing the SV40 origin. J. Biol. Chem. 265:18043-18046.

38. Ishimi, Y., A. Claude, P. Bullock, and J. Hurwitz. 1988. Complete enzymatic synthesis of DNA containing the SV40 origin of replication. J. Biol. Chem. 263:19723-19733.

39. Johnston, G. C., and R. A. Singer. 1983. Growth and the cell cycle of the yeast Saccharomyces cerevisiae. I. Slowing S-phase or nuclear division decreases the G1 cell cycle period. Exp. Cell Res. 149:1-13.

40. Laskey, R. A., M. P. Fairman, and J. J. Blow. 1989. S-phase of the cell cycle. Science 246:609-614.

41. Longhese, M. P., L. Jovine, P. Plevani, and G. Lucchini. 1993. Conditional mutations in the yeast DNA primase genes affect different aspects of DNA metabolism and interactions in the DNA polymerase $\alpha$-primase complex. Genetics 133:183-191.

42. Lucchini, G., M. Muzi Falconi, A. Pizzagalli, A. Aguilera, H. L. Klein, and P. Plevani. 1990. Nucleotide sequence and characterization of temperature-sensitive poll mutants of Saccharomyces cerevisiae. Gene 90:99-104.

43. Miyazawa, H., M. Izumi, S. Tada, R. Takada, M. Masutani, M. Ui, and F. Hanaoka. 1993. Molecular cloning of the cDNAs for the four subunits of mouse DNA polymerase $\alpha$-primase complex and their gene expression during cell proliferation and the cell cycle. J. Biol. Chem. 269:8111-8122. 
44. Murakami, Y., and J. Hurwitz. 1993. DNA polymerase $\alpha$ stimulates the ATP-dependent binding of simian virus tumor T antigen to the SV40 origin of replication. J. Biol. Chem. 268:11018-11027.

45. Murakami, Y., C. R. Wobbe, L. Weissbach, and J. Hurwitz. 1986. Role of DNA polymerase $\alpha$ and DNA primase in simian virus 40 DNA replication. Proc. Natl. Acad. Sci. USA 83:2869 2873.

46. Murray, A. W. 1992. Creative blocks: cell cycle checkpoints and feedback controls. Nature (London) 359:599-604.

47. Nascheuer, H. P., A. Moore, A. F. Whal, and T. S. F. Wang. 1991. Cell cycle dependent phosphorylation of human DNA polymerase $\alpha$. J. Biol. Chem. 266:7891-7903.

48. Nasmyth, K. 1993. Control of the yeast cell cycle by the Cdc28 protein kinase. Curr. Opin. Cell Biol. 5:166-179.

49. Nurse, P. 1990 . Universal control mechanism regulating onset of $M$ phase. Nature (London) 344:503-508.

50. Panzeri, L., L. Landonio, A. Stotz, and P. Philippsen. 1985. Role of conserved sequence elements in yeast centromere DNA. EMBO J. 4:1867-1874.

51. Pizzagalli, A., P. Valsasnini, P. Plevani, and G. Lucchini. 1988. DNA polymerase I gene of Saccharomyces cerevisiae: nucleotide sequence, mapping of a temperature-sensitive mutation, and protein homology with other DNA polymerases. Proc. Natl. Acad. Sci. USA 85:3772-3776.

52. Plevani, P., M. Foiani, M. Muzi Falconi, A. Pizzagalli, C. Santocanale, S. Francesconi, P. Valsasnini, A. Comedini, S. Piatti, and G. Lucchini. 1988. The yeast DNA polymeraseprimase complex: genes and proteins. Biochim. Biophys. Acta 951:268-273.

53. Plevani, P., M. Foiani, P. Valsasnini, G. Badaracco, E. Cheriathundam, and L. M. S. Chang. 1985. Polypeptide structure of DNA primase from a yeast DNA polymerase-primase complex. J. Biol. Chem. 260:7102-7107.

54. Plevani, P., S. Francesconi, and G. Lucchini. 1987. The nucleotide sequence of the PRII gene related to DNA primase in Saccharomyces cerevisiae. Nucleic Acids Res. 15:7975-7989.

55. Pringle, J. R. 1978. The use of conditional lethal cell cycle mutants for temporal and functional sequence mapping of cell cycle events. J. Cell. Physiol. 95:393-406.
56. Pringle, J. R., R. A. Preston, A. M. Adams, T. Stearns, D. G. Drubin, B. K. Haarer, and E. W. Jones. 1989. Fluorescence microscopy methods for yeast. Methods Cell Biol. 31:357-435.

57. Reed, S. I. 1992. The role of p34 kinases in the G1 to S-phase transition. Annu. Rev. Cell Biol. 8:529-561.

58. Roberts, J. M. 1993. Turning DNA replication on and off. Curr. Opin. Cell Biol. 5:201-206.

59. Rose, M. D., F. Winston, and P. Hieter. 1990. Methods in yeast genetics: a laboratory course manual. Cold Spring Harbor Laboratory Press, Cold Spring Harbor, N.Y.

60. Rowley, A., G. C. Johnston, B. Butler, M. Werner-Washburne, and R. A. Singer. 1993. Heat shock-mediated cell cycle blockage and G1 cyclin expression in the yeast Saccharomyces cerevisiae. Mol. Cell. Biol. 13:1034-1041.

61. Sambrook, J., E. F. Fritsch, and T. Maniatis. 1989. Molecular Cloning: a laboratory manual, 2nd ed. Cold Spring Harbor Laboratory Press, Cold Spring Harbor, N.Y.

62. Santocanale, C., M. Foiani, G. Lucchini, and P. Plevani. 1993. The isolated 48,000 -dalton subunit of yeast DNA primase is sufficient for RNA primer synthesis. J. Biol. Chem. 268:13431348.

63. Santocanale, C., F. Locati, M. Muzi Falconi, A. Piseri, B. Y. Tseng, G. Lucchini, and P. Plevani. 1992. Overproduction and functional analysis of DNA primase subunits from yeast and mouse. Gene 113:199-205.

64. Sikorski, R. S., and P. Hieter. 1989. A system of shuttle vectors and yeast host strains designed for efficient manipulation of DNA in Saccharomyces cerevisiae. Genetics 122:19-27.

65. Slater, M. L. 1973. Effect of reversible inhibition of deoxyribonucleic acid synthesis on the yeast cell cycle. J. Bacteriol. 113:263-270.

66. Tsurimoto, T., T. Melendy, and B. Stillman. 1990. Sequential initiation of lagging and leading strand synthesis by two different polymerase complexes at the SV40 DNA replication origin. Nature (London) 346:534-539.

67. Wang, T. S. F. 1991. Eukaryotic DNA polymerases. Annu. Rev. Biochem. 60:513-552.

68. Weinert, T. A., and L. H. Hartwell. 1993. Cell cycle arrest of $c d c$ mutants and specificity of the RAD9 checkpoint. Genetics 134:63-80. 